$1-1993$

\title{
School-Based Management: Strategies for Success
}

University of Pennsylvania

Follow this and additional works at: https://repository.upenn.edu/cpre_policybriefs

Part of the Educational Administration and Supervision Commons, and the Educational Methods Commons

\section{Recommended Citation}

University of Pennsylvania. (1993). School-Based Management: Strategies for Success. CPRE Policy Briefs.

Retrieved from https://repository.upenn.edu/cpre_policybriefs/49

This document was authored by the Consortium for Policy Research in Education, but no individual authors were identified.

View on the CPRE website.

This paper is posted at ScholarlyCommons. https://repository.upenn.edu/cpre_policybriefs/49

For more information, please contact repository@pobox.upenn.edu. 


\title{
School-Based Management: Strategies for Success
}

\author{
Abstract \\ This issue of CPRE Finance Briefs offers a new definition of school-based management and describes \\ strategies for decentralizing management to improve the design of SBM plans. The design strategies \\ focus on the four components of control: power, knowledge, information, and rewards. \\ Research on the private sector shows large-scale change, such as decentralization, cannot be simply \\ installed. Rather it unfolds over time through a gradual learning process. Therefore, the transition to SBM \\ is best approached by establishing structures and processes that enable groups of people to discuss new \\ directions, try new approaches, and learn from them. The second part of this finance brief offers \\ strategies for managing the change to school-based management. \\ Disciplines \\ Educational Administration and Supervision | Educational Methods

\section{Comments} \\ This document was authored by the Consortium for Policy Research in Education, but no individual \\ authors were identified. \\ View on the CPRE website.
}




\section{School-Based Management: Strategies for Success}

School leaders across the nation are exploring ways to better educate students and improve school performance. School-based management (SBM) offers a way to promote improvement by decentralizing control from central district offices to individual school sites. It attempts to give school constituentsadministrators, teachers, parents and other community members-more control over what happens in schools.

Endorsed by many organizations, including the National Governors' Association, SBM is being tried in districts of varied size and wealth. But so far, we have only a small bit of knowledge about how to make SBM work.

Decentralized management has a longer history in the private sector, however. For several decades, organizations have been implementing "high-involvement management," a practice that like SBM decreases centralized control to encourage self-management by employees. ${ }^{1}$ Studies of decentralization in the private sector suggest that high-involvement management is most appropriate in organizations where the work (like teaching in schools) is complex; is best done collegially or in teams; involves uncertainty in its day-to-day tasks; and exists in a rapidly changing environment.

\footnotetext{
${ }^{1}$ For a complete discussion of the concept of high involvement management see, The Ultimate Advantage (San Francisco: JosseyBass, 1992) and High Involvement Management (San Francisco: Jossey-Bass, 1986), both by E. E. Lawler.
}

Research on the private sector also points out that control over four resources needs to be decentralized throughout the organization in order to maximize performance improvement:

- power to make decisions that influence organizational practices, policies and directions;

- knowledge that enables employees to understand and contribute to organizational performance including technical knowledge to do the job or provide the service, interpersonal skills, and managerial knowledge and expertise;

- information about the performance of the organization, including revenues, expenditures, unit performance, and strategic information on the broader policy and economic environment; and

- rewards that are based on the performance of the organization and the contributions of individuals.

This issue of CPRE Finance Briefs offers a new definition of school-based management and describes

Priscilla Wohlstetter is assistant professor of politics and policy in the School of Education at the University of Southern California where she is directing the School-Based Management Project for the Finance Center of the Consortium for Policy Research in Education. Susan Albers Mohrman is deputy director of the School-Based Management Project and senior research scientist with the Center for Effective Organizations, in the School of Business at the University of Southern California.
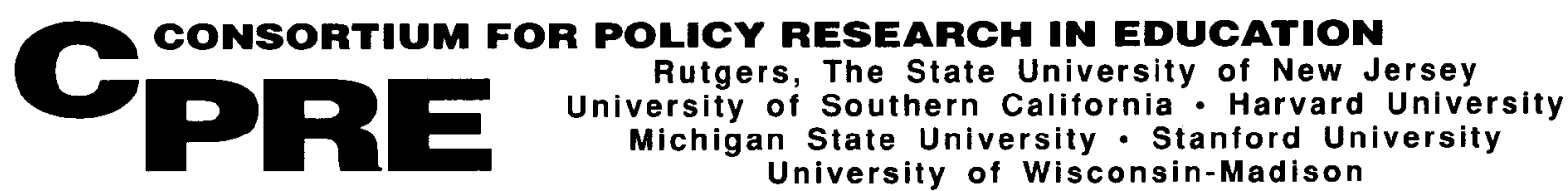
strategies for decentralizing management to improve the design of SBM plans. The design strategies focus on the four components of control: power, knowledge, information, and rewards.

The brief draws from a national study of school-based management being conducted by Priscilla Wohlstetter and Susan Albers Mohrman for the Finance Center of the Consortium for Policy Research in Education (CPRE) and is based on a series of commissioned papers (see sidebar). Researchers are studying public schools, private schools and private companies, that have decentralized in order to identify strategies that can improve the implementation of school-based management and enhance school productivity.

Research on the private sector shows large-scale change, such as decentralization, cannot be simply installed. Rather it unfolds over time through a gradual learning process. Therefore, the transition to SBM is best approached by establishing structures and processes that enable groups of people to discuss new directions, try new approaches, and learn from them. The second part of this finance brief offers strategies for managing the change to school-based management.

\section{School-Based \\ Management: Lessons About What Works}

In the education arena, schoolbased management has been viewed largely as a political reform that transfers power (authority) over budget, personnel and curriculum to individual schools. Little attention has been given to empowering school sites with control over information, professional development (knowledge) or compensation systems

\section{New Book Will Focus on School-Based Management}

This brief is based on the following papers prepared for a study being conducted by the Finance Center of CPRE. The papers will be published in a book tentatively titled Designing High Performance Schools: Strategies for School-Based Management (San Francisco: Jossey-Bass, forthcoming).

Johnson, S. M. \& K. C. Boles. "School-Based Management and Teachers: Strategies for Reform"

Marsh, D. D. \& I. Straus. "The Relationship of Site-Based Management, The Local Change Process and School Transformation: A Review of the Literature"

Mohrman, S. A. "High Involvement Management: An Overview of Practice in the Private Sector"

Mohrman, S. A. "Large-Scale Organizational Change Processes: The Transition to High Involvement Management"

Ogawa, R. T. "School-Based Management: Efforts to Distribute Power, Information, Rewards and Knowledge"

Powell, A. G. "Site Autonomy and Independent Schools: Sustaining Adult Community"

Wohlstetter, P. \& R. Smyer. "Decentralization Strategies: A Review of the Effective Schools Literature"

(rewards). Furthermore, when SBM programs are analyzed, the general conclusion is that the extent of decision-making responsibility transferred to site teachers and administrators is limited.

Experience from the private sector suggests that to effectively implement school-based management, districts need to design plans that not only transfer real authority to school sites but also expand the definition of SBM to include control over information, knowledge and rewards. Drawing from successful decentralization approaches in public schools and in the private sector, strategies for decentralizing resources in each of these four areas are discussed below.

Power. The main focus of schoolbased management has been the decentralization of power. The question is, "Who at the school site is the power given to?" Power is shifted most often from the central administration to a council at the school site. Councils may be composed of administrators, teachers, parents, community members and sometimes students. In this way, SBM empowers groups who typically have not had much power in managing schools.

The idea of using SBM as a vehicle for giving more authority to classroom teachers is common. Indeed, SBM often is seen as synonymous with empowering teachers. Most districts that instituted SBM through collective bargaining - such as Dade County, Florida and Los Angeles, California-provided teachers with majority representation on site councils. In doing so, districts simultaneously decentralized power to the schools and elevated teachers' influence to higher levels in the organization. 
sarily considered part of SBM and usually provide much less professional development than is needed.

Districts under SBM have done even less to develop general organizational skills among SBM participants. This is a serious shortcoming, given the focus in many districts on decentralizing functional tasks, such as budgeting and personnel. There also has been an absence of training for district office personnel whose roles likewise change under SBM. Thus, school districts implementing decentralized management need to encourage a wider variety of training experiences that support new operating practices in both the district office and school site.

A common practice in many dis-

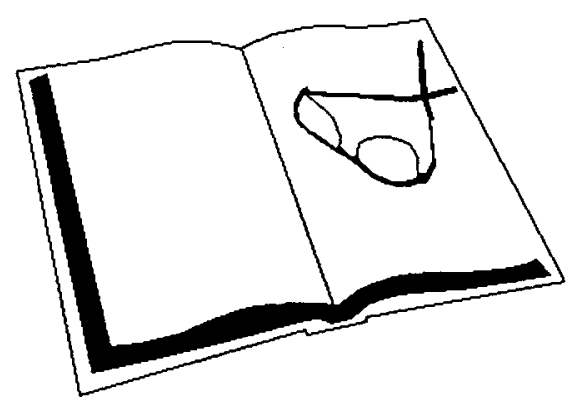

tricts is to have district offices provide training and consulting services to the schools. Implicit in such plans is the belief that central office staff have the knowledge that individuals at the site lack. Sometimes this is true, but often it is not. A few districts have recognized the need to draw upon the knowledge of educators at the school site. For example, Dade County established the Dade Academy for the Teaching Arts which offers training that is planned and operated exclusively by teachers for teachers. Some districts under SBM, such as Chicago, Illinois, and Edmonton, Canada, allow schools to purchase staff development services from experts outside the district.
Although there is yet very little research about the role of new knowledge in SBM, lessons from the private sector suggest that participants in the process need a complex understanding of both decentralized school governance and instructional reform. However, it does not appear that the only strategy for increasing knowledge lies in moving curriculum and instruction experts from the central office to the schools. Rather, studies indicate that the more promising approaches are joint efforts. These efforts draw upon the knowledge of teachers, administrators and outside experts and feature ongoing staff development in which participants at all levels enrich the system with their acquired knowledge and insight, while drawing on new sources of understanding.

Information. Power can only be decentralized if the individuals to whom power is entrusted have access to the information necessary to make good decisions. In the private sector, as well as in public education, much information historically has been available only at the top of the organization.

Companies practicing highinvolvement management have developed ways to collect and share information about organizational goals, finance and cost structures, environmental issues, the customer and organizational performance. The companies provide trend and "benchmark" data to allow units to compare their performance over time, and with other organizational units and other organizations in the field. Further, they find ways to disseminate innovations that are occurring in their organization and in other organizations that are dealing with the same issues.

Public schools implementing decentralized management have not focused much attention on sharing information among participants, particularly at the school site. Indeed, the major focus in districts under SBM appears to be how information is shared vertically between individual schools and the district office, and whether schools are adhering to regulatory policies. Many districts provide schools with standardized test data.

School districts under SBM, however, are only beginning to provide sites with the information about organizational performance needed to develop school-based plans, for instance. To the extent schools are expected to meet districtwide goals, individuals at the school site need information about their performance relative to those goals. In addition, schools, like companies, must have information about their performance relative to other schools, whether or not they are competing with others as in a market-based choice plan.

Finally, schools need information about the extent to which they are meeting their clients'-parents and students-needs. All such information, moreover, needs to be available to schools in a timely fashion, so that modifications can be made inroad to improve organizational performance.

A mission statement is one tool that can be used by educators at the school site to help them to define school goals, measure progress toward reaching the goals, and to share information with the community-at-large. Research in the 1980s on effective schools found many of them have written mission statements defining the school culture and environment. Such information also is prevalent at independent schools whose survival depends on their ability to communicate unique attributes to prospective parents and students. Independent schools 
also stress business information since sound finances, information about tuition, salaries, enrollments, sources of income and types of expenditures also are crucial to the schools' survival.

Besides the content of information, how information is transmitted to the school community is important. With public schools, informal methods of communication are most prevalent: parentteacher conferences, collegial sharing among teachers, and ad hoc meetings with visible, accessible administrators. By contrast, independent schools tend to favor more formalized approaches for transmitting information. Explicit written codes of conduct have become the norm.

Procedures dealing with conflict management, faculty compensation, job descriptions, strategic plans, and methods and timetables for meeting goals are typically written down and distributed to the school community. This written information is one way heads of independent schools communicate the school's mission to the community.

Studies in the 1980 s of effective public schools suggest that they also transmit formal written information about performance expectations for students and staff, but not to the extent of independent schools.

School districts under SBM need to develop more systematic and varied strategies for sharing information at the school site, as well as with the district office and with other schools serving similar student populations. Portfolio assessments, such as those used in Vermont and districts such as Pittsburgh, Pennsylvania, Rochester, New York, and San Diego, California, may be one way to broaden information systems and provide feedback on school productivity.

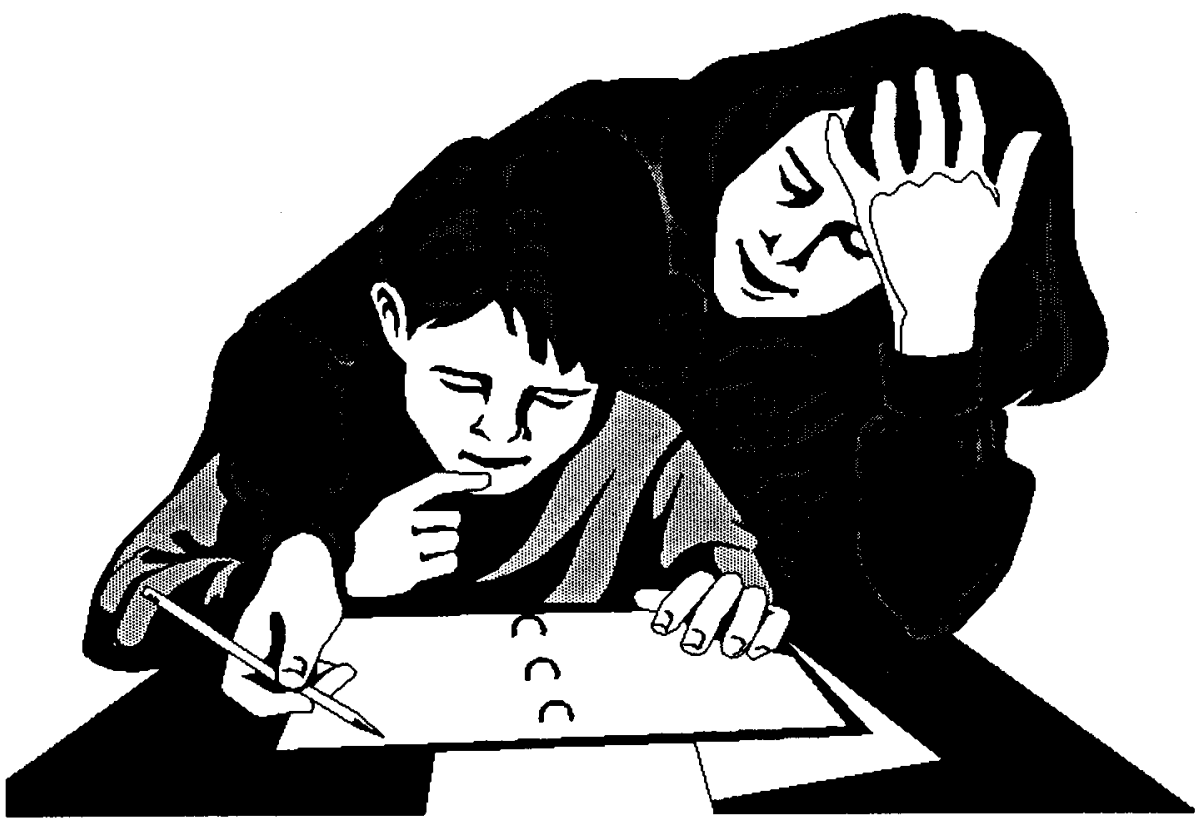

Rewards. Translating decentralized reward structures of business to education is probably the greatest challenge to SBM. Skills-based pay schemes in decentralized private sector organizations reward employees for the knowledge and skills they possess. In education, reward systems tend to use indirect, proxy measures of knowledge and skills, namely the years of education and experience a teacher has accumulated. $^{2}$

Decentralized management plans in the private sector often include components that reward employees collectively for performance. A key lesson from the private sector is that decentralized management is most effective when there is consensus on performance measures and units can be held accountable for performance. Employees need to see the relationship between pay and performance. Such conditions, however, do not often exist in education. Furthermore, it is un-

\footnotetext{
${ }^{2}$ For a detailed discussion of alternative skills-based pay systems in education, see Odden, A. R. \& S. Conley. "Restructuring Teacher Compensation Systems," in Odden, A. R. (Ed.), Rethinking School Finance: An Agenda for the 1990s (San Francisco: Jossey-Bass, 1992).
}

derstood in the private sector that high performance will lead to greater profits, but funding in public education is rarely affected by evidence about performance.

Few districts engaged in SBM have decentralized financial rewards. Teachers continue to be paid on a standardized salary scale and districts continue to allocate funds on a per pupil basis. The issue of performance-based rewards in schools is elusive for many reasons, including the multitude of purposes that various stakeholders have for the schools, the value differences that divide educators and the community, and the resistance of teachers and teacher organizations to the concept.

For example, policymakers often like the idea of rewarding successful schools with more resources, but budget constraints often would oblige them to allocate less to schools that are failing, an untenable approach to school improvement. Competitive merit pay plans exist in a few places. However, the systems tend to differentiate little among teachers and schools, and tend not to last over time. 
Several districts actively involved in SBM continue to develop districtwide career ladders. However, such reforms typically are not skills-based pay schemes but strategies for increasing the pay of teachers who take on more work. For example, both Cincinnati, Ohio and Rochester identify lead teachers who assume special responsibilities and earn extra pay.

Monetary rewards are not the only extrinsic (or external) motivator available. Other possibilities include sabbaticals or opportunities to pursue full-time studies. In addition, prestigious mentor teacher positions could be created to help guide less experienced teachers. Another possibility would be to provide teachers with opportunities to further their education through professional conferences, classes at local colleges and universities, or involvement in teacher networks focused on some aspect of curriculum, teaching and assessment.

It is clear from research about work in schools that an effective reward system also must include opportunities for achieving intrinsic (internal) rewards. There is substantial evidence that although pay is an important concern, many teachers are motivated strongly by intrinsic factors such as achieving success with students or enjoying collaborative work with peers.

Consider, for example, teachers in independent schools who are paid considerably less than their public school counterparts. The evidence suggests non-monetary factors-an environment conducive to learning, seeing positive results in student performance and control of the classroom-motivate these teachers.

School districts under SBM need to devise new approaches-both extrinsic and intrinsic-to reward participants. Rewards can motivate individuals to use their enhanced resources (power, information and knowledge) to further districtwide and school-based goals. Rewards also can be used to align the goals of people at the district office and school sites who have different preferences and value different outcomes.

\section{Managing the Change to SBM}

The transition to SBM entails large-scale change in educational organizations. Successful decentralization requires that systems and processes be redesigned so that power, knowledge, and information accrue at the operating levels of the school, and so that rewards are contingent on performance and contribution. New recruitment practices are needed to attract people who will thrive on the challenge of working in a decentralized setting; development practices must be altered and greatly supplemented to ensure that participants have needed competencies.

The transformation eventually involves all organizational components, including strategy, structure, technology, processes, rewards and other human resources systems. All of these components need to fit with the new way of managing and with each other.

Large-scale change is threatening to the people involved, because it entails new roles and responsibilities and because it challenges traditional assumptions and values. The change process has to be carefully managed. Several change management strategies are discussed below.

Vision. Large-scale change such as a transition to SBM is such a disruption of the status quo of an organization that it will not be successful unless a compelling case is made for it. Districts embarking on SBM should be very clear about the need for change and the ultimate purpose of the change process.

In the private sector, need is clearly established by the marketplace-by the changes that are required to successfully compete and to meet the demands of customers. School districts will have to make a case for the need for change based on gaps in the schools' abilities to meet demands being placed on them and to provide educational services needed by their communities.

Understanding the need for change is the first step in a transition. Having a vision of what the change entails and what it is trying to accomplish is the next. This includes defining high performance in a manner that can be agreed to by the various stakeholders who become partners in the effort. An explicit focus on educational outcomes frames the change to SBM in a way that replaces issues of who gains and who loses power. Developing a shared vision of the organization links people together and provides goals and criteria for change activities and ongoing decisions. School districts and the schools within them should involve stakeholders at all levels in forming the vision, and then in giving it substance at the local level. Superintendents and principals will play a key role in making this happen.

Change structures and roles. In school-based management, creating and empowering the site council often has been the main change intervention. The council is expected to make decisions to change the nature and effectiveness of the education that goes on in the school. Thus, councils become change agents in schools, and should be educated accordingly. 


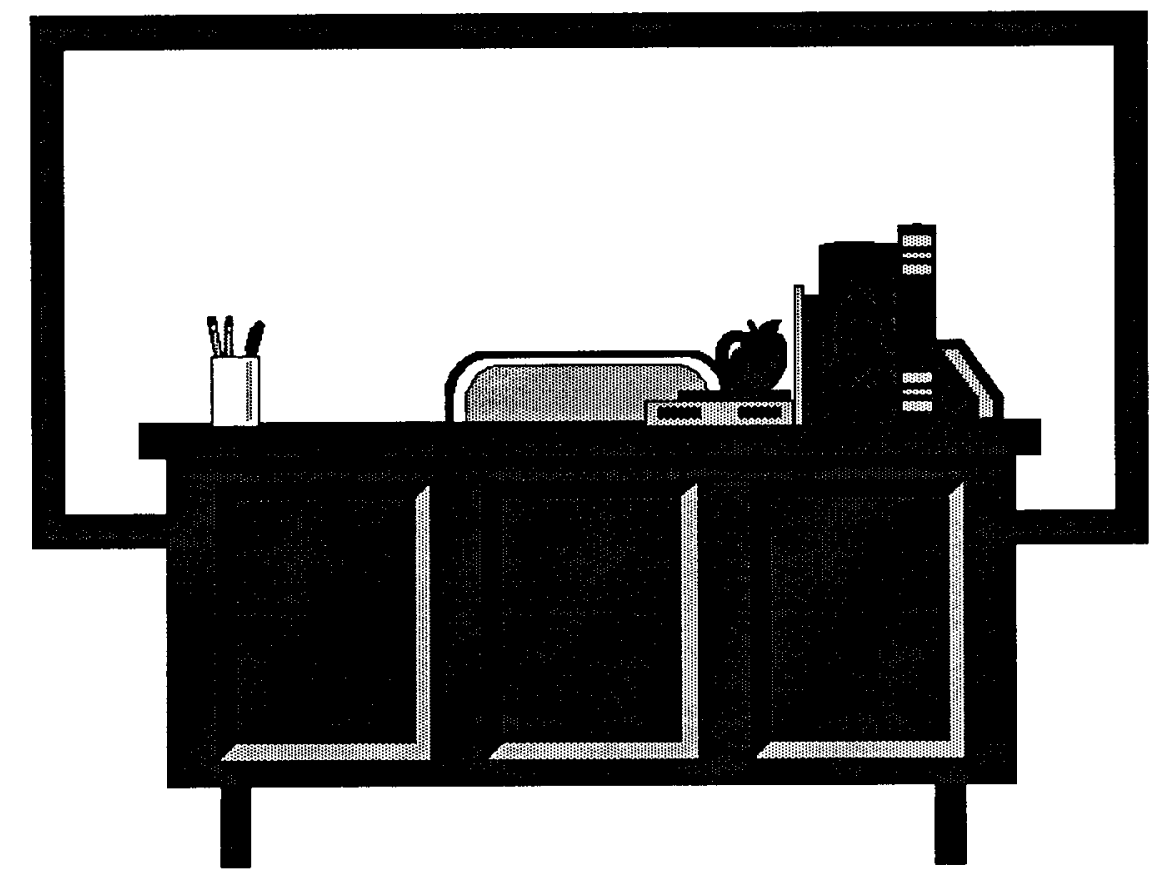

They will have to know how to design change in the school and how to manage the dynamics of change, including the natural stages of transition and the resistance that is associated with it.

In addition, as implementation unfolds, the council will likely spawn other change structures to develop and implement new approaches, and the work of various change groups will have to be coordinated and nurtured.

In the private sector, multistakeholder steering groups have needed education regarding their own group process, organizational design principles and change management approaches. Although SBM councils often receive training in group process, a more extensive set of skills and knowledge will be required, if the council is to play out its potential to spur meaningful change and improvement in the school.

The role of school managementprincipals and superintendentshas not received much attention in SBM plans. Private sector experience has found that such roles are
The role of teachers also changes in a fundamental way. Although they have always managed their own classrooms, SBM implies an extension of their focus to include participating in shaping the school environment, creating the school vision, working with other stakeholders to determine goals and objectives, and taking responsibility for resource allocation and use. Their influence shifts from individual control over their classroom domain to influence exercised in a variety of collective forums, including councils, problem-solving groups, and various kinds of work teams.

Other roles also change extensively. Participation by parents, students and other community stakeholders on school councils implies a basic shift from advocating personal viewpoints to participating in a forum that must take a schoolwide view and address the concerns of many different stakeholders.

This will require considerable team building to develop trust and willingness to work through differences and develop a consensus.

Even the role of district staff changes from planning and overseeing various aspects of school functioning to becoming responsive service groups whose customers are the operating units in the schools. Increasingly these groups will exist to support changes emanating from the schools rather than to initiate change that will be rolled out to the schools.

In sum, the transition to SBM involves extensive change in roles that must be accompanied by intensive development of new skills and capabilities. It cannot be understood simply as a transfer of power. Rather, it is the establishment of new and vital roles for 
many stakeholders, and it will not succeed unless development is planned and resources are provided.

Resources. In the private sector, the transition to decentralized management has been found to unfold over a minimum of three to five years, during which the capabilities of the organization are gradually enhanced and the systems, processes and structures are brought slowly into alignment with the new decentralized vision. This process requires a tremendous amount of resources: time, energy and money. It is an investment in the capabilities of the organization.

Among the key resources are time and money for the extensive skillsdevelopment process required to support the new way of functioning. Development of individuals' capabilities and team development of the various councils and other collaborative structures require finding expertise to help with the process and time for it to occur. Schools will have to find ways to free-up participants for such development.

In addition, school districts will have to invest in the development of new site-based information systems, including measurement and feedback systems, financial and budgeting systems, and new reward systems. The development of these systems will take expert time, but also should be done in a participative way so that the various stakeholders understand and help shape them. Again, this involves freeing up people to participate.

\section{State and Local Policy Implications}

Redesigning educational systems to improve student learning and

\section{CPRE Finance Center Working Papers on School-Based Management}

The following working papers related to school-based management are available from the CPRE FINANCE CENTER with a $\$ 10.00$ pre-payment for each paper. Please make checks payable to the University of Southern California/CPRE and send your requests to: CPRE Finance Center, USC School of Education, Waite Phillips Hall 901, Los Angeles, CA 90089-0031.

\author{
Applying Employee Involvement in Schools \\ Edward E. Lawler, Susan Albers Mohrman, Allan M. \\ Mohrman Jr. \\ December 1991, $14 \mathrm{pp}$.
}

\section{Rethinking Site-Based Management Policy and Research \\ Allan Odden and Priscilla Wohlstetter \\ S.ptember 1991, 11 pp.}

\section{What Can U.S. Charter Schools Learn From England's Grant-Maintained Schools?}

Priscilla Wohlstetter and Lesley Anderson April 1992, $10 \mathrm{pp}$.

\section{Decentralization Strategies: A Review of the Effective Schools Literature}

Priscilla Wohlstetter and Roxanne Smyer September 1992, $29 \mathrm{pp}$.

High Involvement Management: An Overview of Practice in the Private Sector

Susan Albers Mohrman

September 1992, 13 pp.
School-Based Management and Teachers: Strategies for Reform

Susan Moore Johnson and Katherine C. Boles September 1992, 44 pp.

Decentralizing Dollars Under School-Based Management: Have Policies Changed?

Priscilla Wohlstetter and Thomas Buffett

This article is available from Corwin Press, Educational Policy, Vol. 6 No. 1, March 1992, 35-54.

\section{Rethinking School Finance Allan Odden, Editor}

This book discusses finance issues related to important topics of education reform such as: paying teachers for productivity, school site management, incentives, choice, coordinated social services for children, and interstate disparities. The book can be ordered for $\$ 28.95$ from: Jossey-Bass, 350 Sansome Street, San Francisco, CA 94104. 


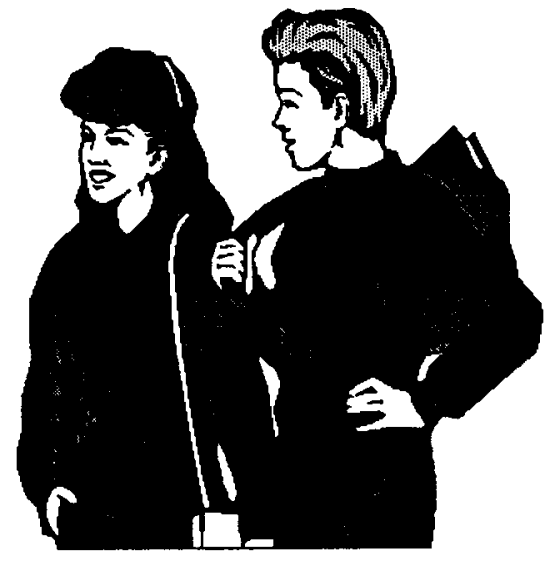

school performance requires considerable initiative and effort by individuals at the school sites. For the process to be successful, however, there also needs to be encouragement and support by those at district and state levels. Here are some initiatives that can be undertaken by states and local school districts based on what we know about successful decentralization in the private sector.

\section{- Power}

States could devise a timeline for transferring budget and personnel authority to school sites and require full transfer by some specified date.

Local districts could exercise oversight over outcomes rather than process. Districts also could take the lead in redefining the role of the central office as supportive rather than compliance-oriented, and encourage the development of new structures at the school site to move power closest to those responsible for educating groups of students.

\section{- Information}

States could develop a prototype information system of fiscal, student, teacher and outcomes data that includes all the key elements needed to engage in SBM. States also could devote resources to disseminating information about educational innovations to SBM participants throughout the state.

Local districts or consortia of local districts could design the computer systems needed to make information available on-line to each school site about how resources are being utilized, satisfaction indicators, achievement indicators, and other relevant measures, so that schools could track trends and compare themselves with similar school units.

\section{- Knowledge and Skills}

States could set aside, over a fiveyear time period, a fixed percentage of total education revenues (23 percent) for professional development that is more in line with skills development budgets at the most productive private companies.

Local districts could initially use those funds to train council members, district and school leaders, and teachers in their new roles and responsibilities. Over time, the funds could be given to schools for use in ongoing, site-based professional development activities.

\section{- Rewards}

States could devote resources to developing templates for a pay system that would include skillsbased pay, cost reduction gainsharing for schools that are able to increase performance while decreasing costs, and other forms of group-based performance pay, like Kentucky is in the process of doing. A state-mandated accountability system could peg performance rewards to a structure of goals and legitimate performance measures.

Local districts could offer to pilot the new pay system in individual schools for which the district has waived personnel regulations, including union contracts. Individual schools, in turn, would have the flexibility to design specific features of the pay system that would make it operational at their school site.

\section{Conclusion}

School-based management is an organizational approach that expands the local school site responsibility and authority for the improvement of school performance. Ideally, it provides local mechanisms for the introduction of new approaches to education that result in enhanced outcomes and that better fill the needs of the local community.

The implementation of SBM represents a fundamental and systemic organizational change to increase the local presence of four key resources: power, information, knowledge and skills, and performance-based rewards. In schools, SBM has been approached largely as a political phenomenon involving the transfer of power to local councils.

Studies of decentralization in the private sector, however, have indicated that decentralization of power is most likely to lead to performance improvement if accompanied by organizational changes that enhance the information, knowledge and skills of local participants and that align the reward system with clearly articulated desired outcomes. This policy brief recommends that states and local districts become active in creating the conditions for effective implementation of SBM.

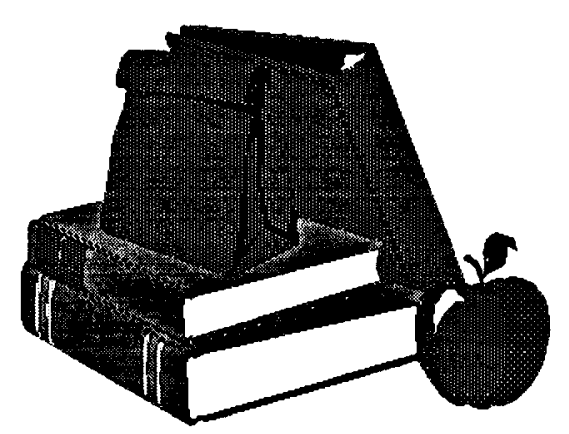

